\title{
Correction to: Siponimod: A Review in Secondary Progressive Multiple Sclerosis
}

\author{
Lesley J. Scott ${ }^{1}$
}

Published online: 18 January 2021

(c) Springer Nature Switzerland AG 2021

\section{Correction to: CNS Drugs (2020) 34:1191-1200 https://doi.org/10.1007/s40263-020-00771-z}

The article Siponimod: A Review in Secondary Progressive Multiple Sclerosis, written by Lesley J. Scott, was originally published electronically on SpringerLink on 27 October 2020 without open access. After publication in volume 34, issue 11, pages 1191-1200, Novartis Pharma AG requested that the article be Open Choice to make the article an open access publication. Post-publication open access was funded by Novartis Pharma AG. Therefore, the copyright of the article has been changed to $\odot$ Springer Nature Switzerland AG 2020 and the article is forthwith distributed under the terms of the Creative Commons Attribution NonCommercial 4.0 International License, which permits any non-commercial use, sharing, adaptation, distribution and reproduction in any medium or format, as long as you give appropriate credit to the original author(s) and the source, provide a link to the Creative Commons licence, and indicate if changes were made. The images or other third party material in this article are included in the article's Creative Commons licence, unless indicated otherwise in a credit line to the material. If material is not included in the article's Creative Commons licence and your intended use is not permitted by statutory regulation or exceeds the permitted use, you will need to obtain permission directly from the copyright holder. To view a copy of this licence, visit http://creativecommons .org/licenses/by-nc/4.0/".

The original article has been corrected.

The original article can be found online at https://doi.org/10.1007/ s40263-020-00771-z.

Lesley J. Scott

demail@springer.com

1 Springer Nature, Mairangi Bay, Private Bag 65901, Auckland 0754, New Zealand
Open Access This article is licensed under a Creative Commons Attribution-NonCommercial 4.0 International License, which permits any non-commercial use, sharing, adaptation, distribution and reproduction in any medium or format, as long as you give appropriate credit to the original author(s) and the source, provide a link to the Creative Commons licence, and indicate if changes were made. The images or other third party material in this article are included in the article's Creative Commons licence, unless indicated otherwise in a credit line to the material. If material is not included in the article's Creative Commons licence and your intended use is not permitted by statutory regulation or exceeds the permitted use, you will need to obtain permission directly from the copyright holder. To view a copy of this licence, visit http://creativecommons.org/licenses/by-nc/4.0/. 